\title{
INTEGRATING ICT IN A DIDACTIC UNIT: LIGHTS, CAMERA, ACTION!
}

\author{
María LUisa Renau Renau \& Beatriz Pérez GarRalón 1 \\ Universitat Jaume I (Castellón, Spain)
}

\begin{abstract}
In Spain, the educational system is focused on traditional teacher-centred methods. Nevertheless, this traditional approach does not engage students anymore. Prensky (2001) claims that students have changed and our educational system was not designed to teach today's students. Today's students are digital natives, they were born into the digital world and they have spent their entire lives using technology. Therefore, taking this into account is paramount to capture the students' interest in class. This work has been designed to integrate the use of ICT in a Spanish high school where traditional approach is the predominant methodology amongst teachers. The didactic unit designed and described in this paper has been implemented in a third year of Compulsory Secondary Education with the objective of combining a traditional approach with a task-based approach. This didactic unit includes the use of ICT in a wide variety of activities in order to deal with diversity awareness and to cope with the different learning styles students may have.

Results indicate that the use of ICT is highly motivating for the students, that students perform better on the tasks which imply the use of computers opposed to the use of traditional materials and that they are willing to work in collaborative groups.
\end{abstract}

Key words: ICT in Secondary Education, collaborative groups, didactic unit implementation.

\section{Introduction}

We live in the so called knowledge society, where innovation of information technologies has led to an outstanding increase in data creation and information dissemination (Vallima and Hoffman, 2008). Trenchs (2001) claims that introducing information and communications technology in the classroom may involve the integration of educational institutions in the real world. This integration would be achieved when students are capable of using the same tools that are being used in the modern world of work. Moreover, ICT can foster real communication and increase the student's exposition to real input. Having access to a wide variety of real input facilitates personalized learning, since the learner may identify with the information presented and the activities proposed. Therefore, the learner will assimilate information more easily and produce comprehensible output (Swain, 1985). This paper contains the description and analysis of a didactic unit designed to integrate the use of information and communications technology in Compulsory Secondary Education.

\section{Theoretical framework}

\subsection{Digital competence and digital natives}

In the last 20 years, the world, and especially the Western culture, has experienced an information and telecommunications revolution. We live in a society where technology plays a paramount role in almost every aspect of our daily lives. The European Commission is aware of the importance of developing the digital competence in this technological era and defends the integration of digital competence in the educational curricula. Before commenting on embedding digital competence in the educational system, we will define the concept of digital competence and digital native. According to Ala-Mutka et al. (2008), "digital

\footnotetext{
1 E -mail : renau@uji.es
} 
literacy consists of the ability to access digital media and ICT, to understand and critically evaluate different aspects of digital media and media contents and to communicate effectively in a variety of contexts". Luzón et al. (2010) quote Leu et al. (2004)'s definition of digital literacy:

The new literacies of the Internet and other information and communication technologies include the skills, strategies, and dispositions necessary to successfully use and adapt to the rapidly changing information and communication technologies and contexts that continuously emerge in our world and influence all areas of our personal and professional lives. These new literacies allow us to use the Internet and other ICTs to identify important questions, locate information, critically evaluate the usefulness of the information, and synthesize information to answer those questions, and then communicate the answer to others.

The European Parliament and the Council (2006) defined digital competence in the EC Recommendation on Key Competences as a competence which "involves the confident and critical use of ICT for employment, learning, self-development and participation in society". As we can see, the definitions provided by Luzón et al. (2010) and by the European Parliament focus on the importance of developing a critical attitude in evaluating and using digital content. We should take into account the fact that "digital competence is an evolving concept related to the development of technology as well as the political aims and expectations for citizenship in a knowledge society" (Ilomäki et al., 2011). When examining the use of internet in Spain, evidence provided by the INE (Instituto Nacional de Estadística) shows that $71.6 \%$ of 16 74 year-olds in Spain have undertaken an internet-related activity in the last three months. That percentage rises up to $97.4 \%$ if we centre our attention on the 16-24 year-olds. It is irrefutable that there is a digital divide when the figures obtained in the survey are broken down by age groups. It is also clear that young people are immersed in the digital world. Prensky (2001) was one of the first scholars to study this digital divide within age groups. He coined and popularized the terms digital native and digital immigrant to define this digital conflict between generations. Prensky (2001) argues that the students of today are digital natives because they "are all 'native speakers' of the digital language of computers, video games and the Internet", and that involves a change in their thinking patterns. On the other hand, those people "who were not born into the digital world but have, at some later point in their lives, become fascinated by and adopted many or most aspects of the new technology are, and always will be compared to them, digital immigrants" (Prensky, 2001). This generates one of the biggest problems facing education today, since "our digital immigrant instructors, who speak an out-dated language (that of the pre-digital age), are struggling to teach a population that speaks an entirely new language" (Prensky, 2001).

\subsection{ICT and the educational paradigm shift}

According to Robinson (2008) "the problem is that the current system education was designed and conceived and structured for a different age. It was conceived in the intellectual culture of the Enlightenment and in the economic circumstances of the Industrial Revolution".

Robinson's view on this matter follows the same train of thought as Prensky (2001), who believes that "our students have changed radically. Today's students are no longer the people our educational system was designed to teach". In contrast to the traditional teaching-learning approach, a new teaching paradigm is emerging. Resta (2002) argues that the new paradigm encompasses the following views of the learning process:

- Learning is a natural process. It is important to take into account that not every student learns in the same way. ICT is useful to create a variety of stimulating activities suiting the different perceptual and personality styles students may have.

- Learning is a social process.

As Vygotsky (1978) noted, students learn best in collaboration with other people and when they perform meaningful tasks. ICTs provide new tools to support this collaborative learning.

- Learning is an active and not a passive process. In life, people usually are asked to produce knowledge, rather than simply reproducing knowledge. Therefore, the educational curricula should 
ask students to think critically and to solve real problems, rather than asking them only to recall what others have accomplished. Learning may either be linear or non-linear.

- Learning is integrative and contextualized. Learners assimilate information more easily when they are asked to make connections within the information provided by the teacher.

- Learning is based on a strength model of student abilities, interest, and culture. In the new educational paradigm, diversity and individual differences are valued.

- Learning is assessed through task completion, products, and real problem solving of both individual and group efforts. Traditional assessment by paper tests is being complemented by collaborative and individual learning tasks.

Ala-Mutka et al. (2008) believe that the educational curricula should be adapted to the society we live in and argue "lifelong learning strategies need to answer to the growing need for advanced digital competence for all jobs and for all learners. Learning digital skills not only needs to be addressed as a separate subject but also embedded within teaching in all subjects".

In order to enable pedagogical innovation with digital competence, Ala-Mutka et al. (2008) give three main recommendations:

- Teachers need to be trained in the digital competence in order to use ICT as a tool used for teaching and also for creating learning activities for their students.

- Students should be encouraged to use ICT for their learning and information searching. This will make students learn how to use digital tools in different fields and with different purposes.

- The use of ICT has the potential to put learners at the centre of the learning process and to promote collaborative work.

Newby et al. (2000) defined the changes in student and teacher roles in learner-centred environments. Table 1 contains a table adapted by Resta (2002) from the one developed by Newby et al. (2000).

Table 1: Changes in Student and Teacher Roles in Learner-Centred Environments

\begin{tabular}{|c|c|}
\hline \multicolumn{2}{|l|}{ Changes in Teacher Role } \\
\hline A shift from: & A shift to: \\
\hline $\begin{array}{l}\text { Knowledge transmitter, primary source of } \\
\text { information, content expert, and source of all } \\
\text { answers. }\end{array}$ & $\begin{array}{l}\text { Learning facilitator, collaborator, coach, mentor, } \\
\text { knowledge navigator, and co-learner. }\end{array}$ \\
\hline $\begin{array}{l}\text { Teacher controls and directs all aspects of } \\
\text { learning. }\end{array}$ & $\begin{array}{l}\text { Teacher gives students more options and } \\
\text { responsibilities for their own learning. }\end{array}$ \\
\hline \multicolumn{2}{|l|}{ Changes in Student Role } \\
\hline A shift from: & A shift to: \\
\hline Passive recipient of information. & Active participant in the learning process. \\
\hline Reproducing knowledge. & $\begin{array}{l}\text { Producing and sharing knowledge, participating at } \\
\text { times as expert. }\end{array}$ \\
\hline Learning as a solitary activity. & Learning collaboratively with others. \\
\hline
\end{tabular}

\subsection{Internet: Web 1.0, Web 2.0 and Web 3.0}

The Internet is a system interconnecting computer networks globally by using the standard Internet protocol suite (TCP/IP). Its origins date back to 1969, when a connection known as Arpanet was established 
between three American universities (Wikipedia). One of the most successful services provided by the Internet is the World Wide Web, also known as WWW or Web. This service has evolved in the last four decades, thus becoming more immediate and dynamic. The term Web 2.0 was created by Darcy DiNucci in his article "Fragmented future" published in 1999 and was popularized by Tim O'Reilly in 2004. Nowadays, experts differentiate between three main types of World Wide Web: Web 1.0, Web 2.0 and Web 3.0. The main characteristic of a Web 1.0 site is that it is a static page where users have a passive role. In Web 1.0 there are only a few content creators, whereas the majority of the Internet users simply consume that content (Cormode and Krishnamurthy, 2008). On the other hand, a Web 2.0 site invites internet users to contribute to the site content and to comment on the information published on the website. Web 2.0 includes blogs, wikis, social networks and media sharing sites. Flew (2008) explains the main differences between Web 1.0 and Web 2.0: "move from personal websites to blogs and blog site aggregation, from publishing to participation, from web content as the outcome of large up-front investment to an ongoing and interactive process, and from content management systems to links based on tagging (folksonomy)". Santiago and Navaridas (2012) claim that the Web 2.0 means a further development of the "traditional" web implying a deeper collaboration, cooperation and interaction amongst cybernauts. Web 3.0 is a term coined by John Markoff (2006) to define a third generation of Internet. Some experts refer to this new generation of World Wide Web as "semantic web" and its definition is object of discussion amongst experts. The main objective of the Web 3.0 is creating content accessible throughout a variety of non-browser applications by creating common formats for integration of data drawn from diverse sources.

\subsection{ICT in education}

The current scenario offers a wide range of technological tools and possibilities which forces teachers to make an adequate selection of the aforementioned tools depending on the activity they want to perform (Palomo et al., 2008). De la Torre (2006) states four essential aspects teachers should consider when creating contents using ICT:

- Access to the content should be universal and easy to find.

- The content created should be interactive.

- Content compilation should be standardized.

- Establishing connections between the content available in the World Wide Web and our previous knowledge.

Moreover, ICT seems to promote the implementation of a learner-centred methodology, which is crucial to foster the learner autonomy (Oster et al., 2006). Thus, students are better prepared to live and work in a society dominated by new technologies, a society that encourages workers towards autonomous training and life long learning. Nevertheless, we should take into account that using ICT does not always imply a better learning. Teachers and students must learn how to use the media; otherwise ICT may become a confusing tool (Alesón and Palazón, 2006)

The following is a brief description of the ICT integrated in the didactic unit analysed in this paper.

\subsubsection{Scavenger Hunt}

A Scavenger Hunt, Treasure Hunt or Knowledge Hunt is essentially a worksheet or a web page containing a series of questions and a list of web pages where the students may find the answers. In the end, the Scavenger Hunt includes a final question, which does not have a direct answer. In order to provide the final answer, the students should reflect upon all the information learnt throughout the Scavenger Hunt and integrate that knowledge (Adell, 2003).

According to Cabero (2007), Scavenger Hunts present the following advantages:

- They can be adapted to different learning levels by means of a gradation. The students can start performing easy tasks and then move to more complicated tasks. 
- They are one of the best ways of presenting the Internet as a learning and information search tool, as well as fostering the learners' autonomy.

- They may be carried out individually or in little groups.

- They may be simple or complicated. The simpler Scavenger Hunts contain fewer questions and fewer links to look for the information required. Older students may work with broader topics and be asked to look for the information in various websites.

\subsubsection{Webquest}

The model of Webquest was first developed by Bernie Dodge in 1995, who defined it as follows: "A WebQuest is an inquiry-oriented activity in which some or all of the information that learners interact with comes from resources on the internet" (Dodge, 1995). Unlike the Scavenger Hunt, the WebQuest implies a process of investigation and transformation of the information obtained. Moreover, WebQuests are always carried out by groups. Each group member adopts a different role in order to foster cooperative work (Pérez, 2006).

\subsubsection{Bitstrips}

Bitstrips is a web and mobile application where users create avatars and comic strips (Wikipedia, 2014). The application has an educational version called Bitstrips For Schools. This software version has the same concept as Bitstrip, but includes a teacher panel, which shows the students' activities and includes permission settings to guarantee student safety and privacy (Tran, 2011).

\subsubsection{OpenOffice Impress}

OpenOffice Impress is an open-source slide show presentation program. The distribution of this program is open, free and accessible, therefore its use with educational purposes is highly recommended. In the didactic unit designed within this project, OpenOffice Impress will be used to create a Teams-gamestournament (DeVries and Edwards, 1973).

\subsubsection{Blogs}

A blog (a contraction of the expression weblog) is a website where one person or various individuals publish articles, known as "posts" or "entries". Usually, these posts cover a single subject and they are displayed in reverse chronological order. Blogs have become very popular because they are easily updateable and facilitate knowledge and opinion sharing. Weblogs are also a powerful tool in an educational setting because writing to the web and interacting with your audience is easy (Richardson, 2006). Fernette and Brock Eide (2005) identified some educational benefits of blogging. They claim that:

- Blogs can promote critical and analytical thinking.

- Blogging can be a powerful promoter of creative, intuitive and associational thinking.

- Blogs promote analogical thinking.

- Blogging is a powerful medium for increasing access and exposure to quality information.

- Blogging combines the best of solidarity reflection and social interaction (Eide Neurolearning Blog, 2005).

\subsection{Diversity awareness and collaborative work}

As stated in the Orden de 18 de junio de 1999 published by the Valencian government, Compulsory Secondary Education is one of the most complex stages in the educational system, since it is a multi-faceted 
stage. On the one hand, Secondary school students should acquire the basic cultural elements, should learn how to accept their duties and defend their rights. On the other hand, students should also be prepared to join the labour market or to continue with their studies, either in professional studies or in Baccalaureat. The law establishes that Compulsory Secondary Education should foster diversity awareness in order to cope with the diverse interests, motivations and skills each student has. A wide range of methodologies adapted to the needs of each student is a good strategy to foster diversity awareness. That is one of the main reasons why this didactic unit includes a variety of methodologies. Collaborative work has also been used in this didactic unit to encourage diversity awareness and take advantage of the strengths of every student. As Kolb (1984) commented, "by bringing together the immediate experiences of the trainees [...] in an open atmosphere where inputs from each perspective could challenge and stimulate the other, a learning environment occurred with remarkable vitality and creativity". According to Quinn (2013), cooperative learning strategies are useful because they: Maximize output with peers. Promote authentic, natural communication. Encourage positive interdependence because learners must rely on each other. Students work with a positive peer group, which facilitates taking risks and decreases pressure to achieve error-free output. Johnson (2009) claims that the effectiveness of cooperation depends on five variables: Positive interdependence. Face-to-face promoted interaction. Individual and group accountability. Social skills. Group processing. We incorporated cooperative learning in this didactic unit using the Team-GameTournament technique, designed by DeVries and Edwards (1973). This technique is used to organize the classroom in teams of four or five members. Each team should be composed by members with a varied command of English. In each turn, one member of each group competes with the other teams by answering questions. The rivals are selected by the teacher to level their skills. All group members have the same opportunities to contribute to their team by winning points for each right answer. Thus, the final reward is collective and the success of each team depends on the achievements of each individual and on the help provided by the teammates.

We also used the Think-Pair-Share technique in one session of this didactic unit. In the Think-Pair-Share technique, the teacher presents a discussion topic. Then, students are given some time to think about that topic on their own. Later, they discuss their ideas with a peer and listen to their partner's ideas. After this pair discussion, students share the outcome with the whole class. This technique, developed by Lyman (1981) is used to make sure that all the students participate in class

\section{Objective}

The main objective of this project is to design a didactic unit combining the traditional language teaching approach with tasks performed using ICT in order to start a transition from the traditional educational system anchored in the curricula and the use of conventional textbooks to a task-based language learning integrating ICT to attract the students' attention and foster collaborative work. In order to do so, the use of Open Office Impress, Bitstrips and a blog created by the teacher has been incorporated in some of the sessions of this didactic unit. The second objective of the project is to teach students how to work in-group and collaborate with their peers by using cooperative learning techniques such as Team-Game-Tournament or Think-Pair-Share. Finally, the results of this combination of methodologies and the use of ICT in the EFL class will be analysed in order to examine the validity of this didactic proposal.

\section{Method}

\subsection{Students and school setting}

This didactic unit has been implemented in the state high school Sos Baynat. This high school is located in Castellón de la Plana. The high school also maintains a close collaboration with the conservatoire Mestre Tàrrega. Thus, about one third of the students enrolled in this high school combine their classes at the high school with the conservatoire lessons. Therefore, most of the students come from a non-problematic family background. They also show high cultural awareness and artistic sensitivity. The human resources of this educative institution gather 53 teachers divided in 18 different departments, and 565 students. The available facilities are 33 classrooms, ten of which are equipped with a computer with access to Internet, a screen projector and speakers. There are also two ICT rooms with 20 computers each. This didactic unit has been implemented in a third year of Compulsory Secondary Education class. There are 15 students participating 
in this project. Before implementing this didactic unit, the students have completed a diagnostic test as initial assessment to determine their level of English. Results show that most of the students have an A2 level of English, according to the Common European Framework of Reference. Nevertheless, three students have a B1 level of English and there is one student with behaviour problems who has an A1 level of English. This diagnostic assessment has been used to design the activities carried out in this unit using the students' command of English as a baseline (Mctighe and O'connor, 2005).

\subsection{Methodology}

This didactic unit includes a variety of teaching methods. In some sessions, a traditional pedagogy is used. For instance, in session 4, students perform a traditional listening comprehension. Nevertheless, most of the sessions have been designed following a task-based approach, according to the definition of task provided by Nunan (2004):

"A piece of classroom work that involves learners in comprehending, manipulating, producing or interacting in the target language while their attention is focused on mobilizing their grammatical knowledge in order to express meaning, and in which the intention is to convey meaning rather than to manipulate form". (Nunan, 2004). The grammar in this unit was introduced by means of a consciousness-raising task. Ellis (1997) defines CR tasks as "a pedagogic activity where the learners are provided with L2 data in some form and required to perform some operation on or with it, the purpose of which is to arrive at an explicit understanding of some linguistic properties of the target language". In the third session of this didactic unit, students read a comic strip where the passive is used. They are asked to reproduce a similar dialogue and deduce the use of the passive. Inquiry-based learning is implemented in the Scavenger Hunt session. In this session, students gather information on the Internet and make meaning of it. This methodology is related to constructivism and the learning theories developed by Piaget, Bruner (1961) and Vygotsky (1962) among others. These theories claim that scaffolding and having initiative are crucial to build knowledge. Teachers' role is helping students to construct knowledge. Communicative approach also plays an important role in this didactic unit. Some sessions include pair-work, class discussion and collaborative work. This approach makes students develop their communication skills in English and acquire communicative competence (Richards, 2006). Communicative language teaching focuses on the students, unlike traditional approaches that focus on the teacher. This learner-centred approach allows the teacher to focus on the specific needs of every student. And in this particular case, by using the CLT in a class with only fifteen students, I was aware of the learning difficulties that they faced and helped them tackle those problems by performing oral consolidation activities.

\subsection{Materials}

This didactic unit requires the use of a computer with Internet connection, a screen and a projector. It would be advisable to provide students with computers with Internet connection during the in-site sessions. If that is not possible, the didactic unit can be adapted and the students can use computers with Internet connection during off-site sessions. This didactic unit has been designed to complement the textbook English in motion 3 used in this school year. Before implementing this didactic unit, the students were asked to complete an English level test and a pre-questionnaire about the use of ICT with educational purposes. The level test contained 25 multiple-choice questions and was used to determine the students' level of English and to design the tasks and activities of this didactic unit adapted to the students' command of English. The pre-questionnaire about the use of ICT contains six questions and was used to determine how often students use ICT in their free time and also with educational purposes. The results of this questionnaire were used to design activities and tasks to catch the students' attention and motivate them. After the implementation of this didactic unit, students completed a post-questionnaire where they had to express their opinion about the tasks and activities that they performed during the eight sessions of this didactic unit. The ICT materials used in this didactic unit are two slide show presentations, two Bitstrips presentation and a blog created by the teacher to post some of the material used in this didactic unit, such as the Scavenger Hunt or the film review model. This blog is available at http://sosbaynatenglish.blogspot.com.es/. Figure 1 shows the first entry of the blog. 
Figure 1: Welcome entry of the blog IES Sos Baynat English

Monday, 27 April 2015

\section{Welcome}

Welcome to the IES Sos Baynat English blog! This blog has been specially designed for the students of 3rd of ESO. Here, they will find extra material related to the topics seen in class.

I hope you like it!

\section{WELCOME!}

Posted by Beatriz Perez at 21:12 No comments:

M $\mathrm{B} \in \mathrm{f}(\mathrm{g}+1$ Recommend this on Google

\subsection{Schedule}

\section{Session 1: Discussing about film genres}

Table 2: Session 1

\begin{tabular}{|l|l|l|l|}
\hline ACTIVITY & OBJECTIVES & METHODOLOGY & TIMING \\
\hline $\begin{array}{l}\text { Speaking about films } \\
\text { students have seen }\end{array}$ & Learning the film genres & $\begin{array}{l}\text { Communicative } \\
\text { approach }\end{array}$ & 10 minutes \\
\hline $\begin{array}{l}\text { Matching films posters with } \\
\text { their film genres }\end{array}$ & Learning the film genres & $\begin{array}{l}\text { Communicative } \\
\text { approach }\end{array}$ & 5 minutes \\
\hline $\begin{array}{l}\text { Matching films genres with } \\
\text { characters from films }\end{array}$ & Learning the film genres & $\begin{array}{l}\text { Communicative } \\
\text { approach }\end{array}$ & 5 minutes \\
\hline $\begin{array}{l}\text { Discussion in pairs about } \\
\text { cinema }\end{array}$ & Interacting orally & $\begin{array}{l}\text { Communicative } \\
\text { approach }\end{array}$ & 15 minutes \\
\hline $\begin{array}{l}\text { Brainstorming: People } \\
\text { involve in a film and parts of } \\
\text { a film }\end{array}$ & Learning vocabulary related & $\begin{array}{l}\text { Communicative } \\
\text { approach }\end{array}$ & 10 minutes \\
\hline $\begin{array}{l}\text { Matching pictures with jobs } \\
\text { related to the cinema }\end{array}$ & $\begin{array}{l}\text { Learning vocabulary related } \\
\text { to films }\end{array}$ & Traditional approach & 5 minutes \\
\hline $\begin{array}{l}\text { Replacing words in } \\
\text { sentences with the new } \\
\text { vocabulary acquired }\end{array}$ & Learning vocabulary related & Traditional approach & 5 minutes \\
\hline
\end{tabular}


Session 2: Reading Films of the Century

Table 3: Session 2

\begin{tabular}{|l|l|l|l|}
\hline ACTIVITY & OBJECTIVES & METHODOLOGY & TIMING \\
\hline Pre-Reading & $\begin{array}{l}\text { Learning vocabulary related to } \\
\text { films. }\end{array}$ & Traditional approach & 5 minutes \\
\hline Reading & $\begin{array}{l}\text { Learning vocabulary related to } \\
\text { films. } \\
\text { Differentiating between active } \\
\text { and passive. }\end{array}$ & $\begin{array}{l}\text { Consciousness-raising } \\
\text { task }\end{array}$ & 20 minutes \\
\hline Post-reading & $\begin{array}{l}\text { Learning vocabulary related to } \\
\text { films. } \\
\text { Differentiating between active } \\
\text { and passive. }\end{array}$ & $\begin{array}{l}\text { Consciousness-raising } \\
\text { task } \\
\text { Communicative } \\
\text { approach }\end{array}$ & 30 minutes \\
\hline
\end{tabular}

\section{Session 3: The passive}

Table 4: Session 3

\begin{tabular}{|l|l|l|l|}
\hline ACTIVITY & OBJECTIVES & METHODOLOGY & TIMING \\
\hline $\begin{array}{l}\text { Reading a comic strip } \\
\text { about the passive }\end{array}$ & $\begin{array}{l}\text { Differentiating between } \\
\text { active and passive }\end{array}$ & $\begin{array}{l}\text { Consciousness-raising } \\
\text { task }\end{array}$ & 25 minutes \\
\hline $\begin{array}{l}\text { Filling in a comic strip } \\
\text { about the passive }\end{array}$ & $\begin{array}{l}\text { Using the present and past } \\
\text { passive }\end{array}$ & $\begin{array}{l}\text { Consciousness-raising } \\
\text { task }\end{array}$ & 10 minutes \\
\hline $\begin{array}{l}\text { Reinforcement passive } \\
\text { exercises }\end{array}$ & $\begin{array}{l}\text { Using the present and past } \\
\text { passive }\end{array}$ & Fill in the gaps & 20 minutes \\
\hline
\end{tabular}

\section{Session 4: World Book Day and Listening}

Table 5: Session 4

\begin{tabular}{|l|l|l|l|}
\hline \multicolumn{1}{|c|}{ ACTIVITY } & \multicolumn{1}{|c|}{ OBJECTIVES } & \multicolumn{1}{c|}{ METHODOLOGY } & TIMING \\
\hline $\begin{array}{l}\text { Slide show presentation } \\
\text { about reading }\end{array}$ & Interacting orally & $\begin{array}{l}\text { Communicative } \\
\text { approach }\end{array}$ & 15 minutes \\
\hline $\begin{array}{l}\text { Matching quotations with } \\
\text { book titles }\end{array}$ & Interacting orally & $\begin{array}{l}\text { Communicative } \\
\text { approach }\end{array}$ & 15 minutes \\
\hline Listening activity & $\begin{array}{l}\text { Learning vocabulary related } \\
\text { to films }\end{array}$ & $\begin{array}{l}\text { Traditional listening } \\
\text { comprehension }\end{array}$ & 15 minutes \\
\hline $\begin{array}{l}\text { Speaking about film } \\
\text { industry jobs }\end{array}$ & $\begin{array}{l}\text { Interacting orally } \\
\text { approach }\end{array}$ & 10 minutes \\
\hline
\end{tabular}


Sessions 5 and 6: Cinema Quiz

Table 6: Sessions 5 and 6

\begin{tabular}{|l|l|l|l|}
\hline ACTIVITY & OBJECTIVES & METHODOLOGY & TIMING \\
\hline $\begin{array}{l}\text { Cinema Quiz: } \\
\text { Pre-task }\end{array}$ & $\begin{array}{l}\text { Using the present and past passive } \\
\text { Working in groups } \\
\text { Creating a film quiz } \\
\text { Interacting in writing }\end{array}$ & $\begin{array}{l}\text { Task-based approach } \\
\text { Collaborative work }\end{array}$ & 20 minutes \\
\hline $\begin{array}{l}\text { Cinema Quiz: While- } \\
\text { task }\end{array}$ & $\begin{array}{l}\text { Using the present and past passive } \\
\text { Working in groups } \\
\text { Creating a film quiz } \\
\text { Interacting orally and in writing }\end{array}$ & $\begin{array}{l}\text { Task-based approach } \\
\text { Collaborative work }\end{array}$ & 35 minutes \\
\hline $\begin{array}{l}\text { Cinema Quiz: } \\
\text { Post-task }\end{array}$ & $\begin{array}{l}\text { Using the present and past passive } \\
\text { Working in groups } \\
\text { Interacting orally }\end{array}$ & $\begin{array}{l}\text { Task-based approach } \\
\text { Collaborative work }\end{array}$ & 55 minutes \\
\hline
\end{tabular}

\section{Session 7: Film review}

Table 7: Session 7

\begin{tabular}{|c|l|l|c|}
\hline \multicolumn{1}{|c|}{ ACTIVITY } & \multicolumn{1}{|c|}{ OBJECTIVES } & \multicolumn{1}{c|}{ METHODOLOGY } & \multicolumn{1}{c|}{ TIMING } \\
\hline \multirow{3}{*}{ Film review } & $\begin{array}{l}\text { Using the present and past passive } \\
\text { Learning linking words } \\
\text { Writing a film review } \\
\text { Interacting orally and in writing }\end{array}$ & Process writing & 55 minutes \\
& & & \\
\hline
\end{tabular}

Session 8: Scavenger Hunt

Table 8: Session 8

\begin{tabular}{|l|l|l|l|}
\hline ACTIVITY & OBJECTIVES & METHODOLOGY & TIMING \\
\hline Scavenger Hunt & $\begin{array}{l}\text { Completing a Scavenger Hunt about } \\
\text { films }\end{array}$ & Inquiry-based learning & 55 minutes \\
\hline
\end{tabular}


Film review assessment rubric

Table 9: Film review assessment rubric

\begin{tabular}{|c|c|c|c|}
\hline & OUTSTANDING & GOOD & POOR \\
\hline Structure & $\begin{array}{l}\text { The text is divided in } \\
\text { three paragraphs } \\
\text { following the model text }\end{array}$ & $\begin{array}{l}\text { The text is divided in } \\
\text { paragraphs but does not } \\
\text { follow the model text }\end{array}$ & $\begin{array}{l}\text { The text is not divided in } \\
\text { paragraphs and does not } \\
\text { follow the model text }\end{array}$ \\
\hline Connectors & $\begin{array}{l}\text { Uses linking words, } \\
\text { including those learnt in } \\
\text { this didactic unit }\end{array}$ & $\begin{array}{l}\text { Uses linking words but does } \\
\text { not include any of the linkers } \\
\text { learnt in this unit }\end{array}$ & $\begin{array}{l}\text { There are very few } \\
\text { connectors ( } 0 \text { to } 2)\end{array}$ \\
\hline $\begin{array}{l}\text { Grammatical } \\
\text { correctness }\end{array}$ & $\begin{array}{l}\text { The text does not } \\
\text { contain any serious } \\
\text { grammar mistake }\end{array}$ & $\begin{array}{l}\text { The text contains } 3 \text { to } 5 \\
\text { serious mistakes such as: } \\
\text {-Subject omission } \\
\text {-Wrong word order } \\
\text {-Irregular verbs errors } \\
\text {-Adjectives written in plural } \\
\text {-3rd person verb without -s. }\end{array}$ & $\begin{array}{l}\text { The text contains more } \\
\text { than } 5 \text { of the mistakes } \\
\text { described in the previous } \\
\text { cell }\end{array}$ \\
\hline $\begin{array}{l}\text { Lexical } \\
\text { variety and } \\
\text { accuracy }\end{array}$ & $\begin{array}{l}\text { Uses a wide range of } \\
\text { vocabulary and includes } \\
\text { the vocabulary learnt in } \\
\text { this didactic unit. }\end{array}$ & $\begin{array}{l}\text { Uses a wide range of } \\
\text { vocabulary but does not } \\
\text { include the vocabulary learnt } \\
\text { in this didactic unit. }\end{array}$ & $\begin{array}{l}\text { The vocabulary is not } \\
\text { varied. It repeats the } \\
\text { same words constantly. } \\
\text { Does not include the } \\
\text { vocabulary learnt in this } \\
\text { unit. }\end{array}$ \\
\hline Content & $\begin{array}{l}\text { The text contains all the } \\
\text { information required } \\
\text { (favourite film, location, } \\
\text { plot, actors and reasons } \\
\text { why they like it) }\end{array}$ & $\begin{array}{l}\text { The text contains most of the } \\
\text { information required }\end{array}$ & $\begin{array}{l}\text { The text does not contain } \\
\text { the information required }\end{array}$ \\
\hline
\end{tabular}

We also designed a rubric to evaluate the performance of each student during the completion of the Scavenger Hunt:

\section{Scavenger Hunt Assessment Rubric}

Table 10: Scavenger Hunt assessment rubric

\begin{tabular}{|c|c|c|c|}
\hline & OUTSTANDING & GOOD & POOR \\
\hline Use of ICT & $\begin{array}{l}\text { The student knows } \\
\text { how to use the blog and } \\
\text { access to the links } \\
\text { provided without } \\
\text { problems }\end{array}$ & $\begin{array}{l}\text { The student knows } \\
\text { how to use the blog and } \\
\text { access to the links } \\
\text { provided with little } \\
\text { difficulty }\end{array}$ & $\begin{array}{l}\text { The student uses } \\
\text { the blog and accesses } \\
\text { to the links provided } \\
\text { with high difficulty }\end{array}$ \\
\hline Focus on the task & $\begin{array}{l}\text { The student is } \\
\text { focused on performing } \\
\text { the task during class }\end{array}$ & $\begin{array}{l}\text { The student } \\
\text { attempts to use the } \\
\text { computer to do other } \\
\text { activities, but focuses } \\
\text { on the task when the } \\
\text { teacher tells him/her to } \\
\text { do so }\end{array}$ & $\begin{array}{l}\text { The student uses } \\
\text { the computer to do } \\
\text { other activities instead } \\
\text { of completing the } \\
\text { Scavenger Hunt }\end{array}$ \\
\hline
\end{tabular}




\begin{tabular}{|l|l|c|c|}
\hline Answers & $\begin{array}{l}\text { Answers correctly to } \\
\text { all the answers in the } \\
\text { Scavenger Hunt }\end{array}$ & $\begin{array}{c}\text { Answers correctly to } \\
\text { three of the answers in } \\
\text { the Scavenger Hunt }\end{array}$ & $\begin{array}{l}\text { Answers correctly to } \\
1-2 \text { answers in the } \\
\text { Scavenger Hunt }\end{array}$ \\
\hline \multirow{3}{*}{ Final answer } & $\begin{array}{l}\text { The final answer } \\
\text { contains a well-argued } \\
\text { idea result of a profound } \\
\text { reflection }\end{array}$ & $\begin{array}{l}\text { The final answer } \\
\text { contains a well-argued } \\
\text { idea but the answer is } \\
\text { not result of a profound } \\
\text { reflection }\end{array}$ & $\begin{array}{l}\text { The student has not } \\
\text { reflected about this } \\
\text { Scavenger Hunt before } \\
\text { answering. }\end{array}$ \\
\hline
\end{tabular}

Furthermore, the students were asked to reflect upon their learning process and their participation in class by filling the following self-assessment chart:

Table 11: Self-assessment chart on participation

\begin{tabular}{|l|l|l|l|}
\hline \multicolumn{2}{|l|}{ Self-assessment chart on participation } & Sometimes & $\begin{array}{l}\text { Hardly ever or } \\
\text { never }\end{array}$ \\
\hline Name: & Always & & \\
\hline $\begin{array}{l}\text { B listened attentively whenever the teacher or my } \\
\text { classmates were speaking. }\end{array}$ & & & \\
\hline I completed the homework assignments. & & \\
\hline $\begin{array}{l}\text { I voluntarily answered a question or made a } \\
\text { contribution. }\end{array}$ & & & \\
\hline I participated actively in the group activities. & & \\
\hline $\begin{array}{l}\text { I let the teacher know if I needed an explanation or } \\
\text { help. }\end{array}$ & & & \\
\hline I tried my best to pay attention during class. & & & \\
\hline $\begin{array}{l}\text { I let the teacher know if I needed an explanation or } \\
\text { help }\end{array}$ & & & \\
\hline
\end{tabular}

Adapted from: http://goo.gl/PgQQt9

\section{Results}

This section contains the results of the initial questionnaire about the use of ICT. The results of this questionnaire have been analysed to determine the importance of ICT in the students' daily lives.

The student's performances in the film review composition and the Scavenger Hunt have also been analysed to determine the results of the implementation of this didactic unit. Their performances have been assessed according to the rubrics shown in tables 10 and 11.

The students were also asked to fill in a final questionnaire reflecting their opinion about this didactic unit.

\subsection{Results of the pre-questionnaire}

The questionnaire about the use of ICT contains six questions and was designed to determine how students use ICT in their free time and in school. The questionnaire contains five multiple-choice questions and one open question.

\subsubsection{Frequency of use of ICT}

The first question asked students how often they used the ICT. The results are shown in table 12. 
Table 12: Students' answer to question 1

\begin{tabular}{|c|c|c|c|}
\hline Daily & At least once a week & At least once a month & Never or hardly ever \\
\hline $100 \%$ & - & - & - \\
\hline
\end{tabular}

According to these results, all the students use the computer, the mobile phone and surf the web on a daily basis.

\subsubsection{ICT skills}

In the second question, students were asked how they would define their ICT skills. The results are shown in table 13.

Table 13: Students' answer to question 2

\begin{tabular}{|c|c|c|c|}
\hline $\begin{array}{c}\text { I come across really } \\
\text { well with ICT }\end{array}$ & $\begin{array}{c}\text { I come across well } \\
\text { with ICT }\end{array}$ & $\begin{array}{c}\text { I only use ICT to surf } \\
\text { the net }\end{array}$ & $\begin{array}{c}\text { I use ICT with great } \\
\text { difficulty }\end{array}$ \\
\hline $53.33 \%$ & $46.66 \%$ & - & - \\
\hline
\end{tabular}

The results of this question show that all the students feel confident with their ICT skills. They consider that they come across well $(46.66 \%)$ or really well $(53.33 \%)$ with the use of Internet and different software such as Office.

\subsubsection{Use of ICT by teachers}

In the third question, students were asked about the use of computers that their teachers do in class. The results are shown in table 14.

Table 14: Students' answer to question 3

\begin{tabular}{|c|c|c|c|}
\hline $\begin{array}{c}\text { Most of the teachers } \\
\text { use computers in } \\
\text { class, with }\end{array}$ & $\begin{array}{c}\text { Only some teachers } \\
\text { use computers in } \\
\text { class frequently }\end{array}$ & $\begin{array}{c}\text { Only some teachers } \\
\text { use computers in } \\
\text { class, but rarely }\end{array}$ & $\begin{array}{c}\text { Only the Computing } \\
\text { teacher uses } \\
\text { computers in class }\end{array}$ \\
\hline- & $26.66 \%$ & $66.66 \%$ & $6.66 \%$ \\
\hline
\end{tabular}

Two thirds of the students said that only some teachers use computers in class, but they do not use them very often. They use them only in some lessons. $26.66 \%$ of the students answered that only some teachers use computers in class frequently.

\subsubsection{Use of Virtual Classroom}

In the forth question, students were asked if they use any virtual platform, such as Moodle, and in which subjects they use it. 
All students answered that the high school provides access to Moodle, but only the English, Valencian, Spanish and Biology teacher use them. They use this virtual platform mainly to download study texts and to submit compositions.

\subsubsection{Use of ICT with educational purposes}

In the fifth question, students were asked if they have ever used ICT with educational purposes. The results are shown in table 15.

Table 15: Students' answer to question 5

\begin{tabular}{|c|c|c|c|}
\hline $\begin{array}{c}\text { I use the Internet to } \\
\text { look for academic } \\
\text { information and I'm in } \\
\text { educational groups in } \\
\text { the social networks }\end{array}$ & $\begin{array}{c}\text { I use Internet to look } \\
\text { for academic } \\
\text { information }\end{array}$ & $\begin{array}{c}\text { I seldom use the } \\
\text { computer with } \\
\text { educational purposes }\end{array}$ & $\begin{array}{c}\text { I have never used the } \\
\text { computer with } \\
\text { educational purposes }\end{array}$ \\
\hline $46.66 \%$ & $46.66 \%$ & $6.66 \%$ & \\
\hline
\end{tabular}

Taking into account these results, $93.33 \%$ of the students use the Internet to look for academic information. Moreover, $46.66 \%$ of the students participate in educational groups in social networks such as Facebook or Tuenti.

\subsubsection{Using computers in class}

In the sixth question, students were asked if they would like to use computers in class more often. The results are shown in table 16.

Table 16: Students' answer to question 6

\begin{tabular}{|c|c|c|c|}
\hline $\begin{array}{c}\text { Yes, because their } \\
\text { use is interesting and } \\
\text { motivates me to learn } \\
\text { more }\end{array}$ & $\begin{array}{c}\text { I would like to use } \\
\text { them in class, but not } \\
\text { always }\end{array}$ & I don't mind & $\begin{array}{c}\text { No, the use of } \\
\text { computers hinders } \\
\text { my learning }\end{array}$ \\
\hline $66.66 \%$ & $13.33 \%$ & $20 \%$ & \\
\hline
\end{tabular}

According to these results, $66.66 \%$ of the students would like to use computers in class more often in order to render the class more interesting and to motivate them to learn. Nevertheless, $20 \%$ of the students declared that they did not mind the use of computers in class.

\subsection{Results of the film review rubric}

Table 17: Results of the film review

\begin{tabular}{|c|c|c|c|}
\cline { 2 - 4 } \multicolumn{1}{c|}{} & OUTSTANDING & GOOD & POOR \\
\hline Structure & $78.57 \%$ & $14.29 \%$ & $7.14 \%$ \\
\hline Connectors & $78.57 \%$ & $14.29 \%$ & $7.14 \%$ \\
\hline $\begin{array}{l}\text { Grammatical } \\
\text { correctness }\end{array}$ & $35.71 \%$ & $50 \%$ & $14.29 \%$ \\
\hline
\end{tabular}




\begin{tabular}{|c|c|c|c|}
\hline $\begin{array}{c}\text { Lexical variety and } \\
\text { accuracy }\end{array}$ & $64.29 \%$ & $28.57 \%$ & $7.14 \%$ \\
\hline Content & $50 \%$ & $35.71 \%$ & $14.29 \%$ \\
\hline
\end{tabular}

Table 17 reflects the students' writing skills when writing a film review. It can be observed that $78.57 \%$ of the students had an outstanding performance regarding the structure of the composition and the use of connectors.

The points which students found more problematic were the grammatical correctness and the content of the review. In both criteria $14.29 \%$ of the students did a poor performance.

It is worth mentioning that one student did not write her film review. Therefore, the percentages of Table 19 have been calculated with a total of 14 students instead of 15 .

\subsection{Results of the Scavenger Hunt rubric}

Table 18: Results of the Scavenger Hunt

\begin{tabular}{|c|c|c|c|}
\cline { 2 - 4 } \multicolumn{1}{c|}{} & OUTSTANDING & GOOD & POOR \\
\hline Use of ICT & $66.66 \%$ & $33.33 \%$ & $0 \%$ \\
\hline Focus on the task & $33.33 \%$ & $46.66 \%$ & $20 \%$ \\
\hline Answers & $60 \%$ & $26.66 \%$ & $13.33 \%$ \\
\hline Final answer & $40 \%$ & $33.33 \%$ & $26.66 \%$ \\
\hline
\end{tabular}

Table 18 reflects the students' skills when completing the Scavenger Hunt. It can be observed that none of the students used the ICT poorly. Only $13.33 \%$ of the students had difficulties when answering the questions in the Scavenger Hunt. That percentage rises to $26.66 \%$ when answering the final question.

\subsection{Results of the post-questionnaire}

The questionnaire is divided into two main sections. In the first section, students grade their agreement with five questions regarding the materials used in class and group work.

The second section contains three open questions, where students explain what they have learned and the activities of this didactic unit that they have enjoyed the most and the least.

\subsubsection{Working with computers}

The students were asked to express their opinion about the sentence: I enjoyed working with computers. The results are shown in table 19.

Table 19: Students' answer to question 1

\begin{tabular}{|c|c|c|c|c|}
\hline Strongly disagree & Disagree & No opinion & Agree & Strongly agree \\
\hline- & - & $6.66 \%$ & $60 \%$ & $33.33 \%$ \\
\hline
\end{tabular}

$93.33 \%$ of the class enjoyed working with computers and one student said that he had no opinion about this matter.

\subsubsection{Working only with the textbook}

The students were asked to express their opinion about the sentence: I prefer working only with the textbook. The results are shown in table 20. 
Table 20: Students' answer to question 2

\begin{tabular}{|c|c|c|c|c|}
\hline Strongly disagree & Disagree & No opinion & Agree & Strongly agree \\
\hline $20 \%$ & $40 \%$ & $40 \%$ & - & - \\
\hline
\end{tabular}

$60 \%$ of the class consider that the textbook should not be the only material used in class and $40 \%$ of the students declared that they had no opinion about this matter.

\subsubsection{Working in group}

The students were asked to express their opinion about the sentence: I enjoyed working in group. The results are shown in table 21.

Table 21: Students' answer to question 3

\begin{tabular}{|c|c|c|c|c|}
\hline Strongly disagree & Disagree & No opinion & Agree & Strongly agree \\
\hline- & - & - & $66.66 \%$ & $33.33 \%$ \\
\hline
\end{tabular}

According to these results, it is clear that all the students enjoyed working in group during this didactic unit.

\subsubsection{Working alone}

The students were asked to express their opinion about the sentence: I prefer working alone. The results are shown in table 22.

Table 22: Students' answer to question 4

\begin{tabular}{|c|c|c|c|c|}
\hline Strongly disagree & Disagree & No opinion & Agree & Strongly agree \\
\hline $13.33 \%$ & $40 \%$ & $20 \%$ & $26.66 \%$ & - \\
\hline
\end{tabular}

This question obtained mixed results: $53.33 \%$ of the students declared that they do not like working alone and $26.66 \%$ stated that they prefer working alone.

\subsubsection{Motivation and use of ICT}

The students were asked to express their opinion about the sentence: I am more motivated with the use of ICT than with traditional materials. The results are shown in table 23.

Table 23: Students' answer to question 5

\begin{tabular}{|c|c|c|c|c|}
\hline Strongly disagree & Disagree & No opinion & Agree & Strongly agree \\
\hline- & $6.66 \%$ & $13.33 \%$ & $46.66 \%$ & $33.33 \%$ \\
\hline
\end{tabular}

A total of $80 \%$ of the class enjoyed working with computers and consider that the use of ICT instead of traditional teaching material such as textbooks or writing in the blackboard motivates their learning.

\subsubsection{Knowledge acquired}

The open question What have you learned? was included in this questionnaire to make students reflect upon what they had learned during the implementation of this didactic unit. The answers were very varied, but most of the students commented on the grammar and vocabulary learned. $40 \%$ of the students also said that they enjoyed this didactic unit because they learned many facts and curiosities about the cinema. 


\subsubsection{Favourite activity}

In this question, students answered to the question What activity did you enjoy most? Why? $66.66 \%$ of the students declared that their favourite activity was the cinema quiz because they enjoyed working in groups and they also discovered many new things about the film industry. $26.66 \%$ of the students declared that their favourite activity was the Scavenger Hunt because they enjoyed working with the computer and reading texts and watching videos in the computer. One student answered that he did not have any favourite activity.

\subsubsection{Activity least enjoyed}

In this question, students answered to the question What activity did you enjoy least? Why? The answers to this question were very varied. $46.66 \%$ of the students declared that they enjoyed all activities of this didactic unit. $26.66 \%$ of the students declared that they did not like copying things from the blackboard or writing in the notebook and $13.33 \%$ said that they did not enjoy working with the textbook. One student said that he did not enjoy learning grammar and another student declared that the activity he enjoyed the least was the cinema quiz.

\section{Discussion}

\subsection{Analysis of the pre-questionnaire}

Results of this questionnaire about the use of ICT amongst students prove that we are dealing with digital learners who use ICT daily and feel confident about their ICT skills. This means that students are willing to use ICT in every context of their daily lives, including the academic context. The students' relation with new technologies contrasts with the use that most teachers make of ICT in class, since two thirds of the students declared that only some teachers use computers in class and on rare occasions. Furthermore, despite being subscribed to the Moodle platform, a small percentage of teachers use this virtual platform to support their classes. Definitely, we can see a technology gap between teenage students and the majority of teachers. The consequences of this gap are evident: Some teachers are afraid of using ICT in class because their technological knowledge is lower than the students' computer skills. Therefore, teachers feel that they may lose control of the class if they introduce ICT in their lessons. However, by leaving new technologies out of the classroom teachers fail to connect with students. In this questionnaire, students declared that they would like to use computers in class more often because ICT motivates them to learn more. In fact, most of the students declared that they already used ICT with educational purposes and $46.66 \%$ of the students stated that they were even participating in educational groups in the social networks such as Facebook.

\subsection{Analysis of the film review rubric}

Results show that students did particularly well regarding the structure of the composition and the use of connectors. This may be due to the fact that the model text was provided by means of a blog and students read it with more attention than when a model text is presented to them in plain paper. Moreover, students knew that their film reviews were going to be posted on the IES Sos Baynat English blog. All these factors resulted in the students paying more attention to the structure of the writing composition. Nevertheless, the use of the blog did not show any impact on the grammatical correctness and the content of the review. The students' performance in these two points was similar to the outcome obtained in previous compositions written by these students.

\subsection{Analysis of the Scavenger Hunt rubric}

Results indicate that using ICT to perform this task did not pose any problems for students. Most of the students were focused on the task they were performing and they were able to answer correctly most of the questions of the Scavenger Hunt. This means that they were able to surf the net and find the information they needed to give the right answers. This reinforces the results of the first questionnaire, where students declared that using ICT in class would motivate them in their learning process. The most difficult part for the 
students was giving a well-reasoned final answer. This may be related to the fact that students are not used to think critically in class and not to the use of ICT.

\subsection{Analysis of the post-questionnaire}

According to the results of this questionnaire, students enjoyed working with computers. In fact, they preferred working with ICT rather than using traditional teaching materials such as the blackboard and the textbook. Certainly, during the implementation of this didactic unit, students were really participative and focused on the tasks they were asked to complete, especially when that implied the use of ICT. Regarding collaborative work, although some students declared that they preferred working alone (26.66\%), all the students said that they enjoyed working in group. Since students were only 15 years old, they still needed guidance to know how to work in group and distribute the work in a meaningful way. But they were eager to follow the teacher's instructions and to work in the groups created by the teacher. According to this questionnaire, the activities that they enjoyed the most were the cinema quiz, the Scavenger Hunt and sharing their film reviews on the English blog. The students explained that they enjoyed particularly the cinema quiz because they liked working in group and they had fun while learning some new vocabulary about films. It is worth mentioning that the level of English of the members of each team was balanced. As a result of this balance between teams, the score was tight during the whole game and that helped in keeping the students' interest during the whole session. Students also enjoyed the Scavenger Hunt because they hardly ever go to the computer room and thanks to this task; they had the chance to change the classroom atmosphere for one day and to work with computers. They said that the activity they enjoyed the least was whenever they had to write in their notebook. Obviously, they need to write in order to improve their writing skills but perhaps we should have designed some tasks to make writing more appealing to them.

\section{Conclusions}

With this paper we implemented a didactic unit combining traditional methodologies with collaborative work and the use of ICT. The use of a blog to create a Scavenger Hunt was a good task to learn how students interact with oral and written texts presented in a virtual format. As stated before, technology is highly present in our society and we need to integrate ICT in education in order to prepare students to live and work in the real world (Trenchs, 2001). The inclusion of ICT in this didactic unit had a positive outcome, since students were proficient in its use and knew how to use the available technological resources in their benefit. Introducing collaborative work in education is also crucial to teach students how to interact in a changing society, which demands teamwork in order to adapt better to those changes. In this case, students reacted positively to collaborative work and were eager to learn how to work with their classmates in a wellstructured and meaningful way in order to take advantage of their own strengths. As a conclusion, the analysis of the results obtained suggests that: Using Information and Communication Technologies is highly motivating for the students. Students perform better on tasks that imply the use of computers because they are more focused than when the work implies the use of traditional materials such as the textbook or the blackboard. Students are willing to work in collaborative groups and to learn how to share the responsibilities of the tasks they are asked to perfume with their peers.

\section{References}

Adell, J. (2003): Internet en el aula: a la caza del tesoro, Edutec, revista electrónica de tecnología educativa, 16. Retrieved from http://edutec.rediris.es/revelec2/revelec16/adell.html

Ala-Mutka, K., Punie, Y. \& Redecker, C. (2008). Digital competence for lifelong learning. Jrc Technical Note 48708, Office for Official Publications of the European Communities, Luxemburg. Retrieved from ftp://ftp.j.jc.es/pub/eurdoc/eurdoc/jrc48708.tn.pdf

Alesón Carbonell, M. \& Palazón Speckens, M. (2006). El profesor, el alumno y las TIC: hacia un aprendizaje más autónomo. In Oster, U., Ruiz Madrid, M. N. \& Sanz Gil, M. (Eds.). Towards the integration of the ict in language learning and teaching: reflection and experience. Servei de Publicacions de la Universitat Jaume I, Castelló. 
Aronson, E. (1971). History of the Jigsaw Classroom. Retrieved from http://www.jigsaw.org/history.htm

Bruner, J.S. (1961). The act of discovery, Harvard educational review. Retrieved from https://digitalauthorshipuri.files.wordpress.com/2015/01/the-act-of-discovery-bruner1.pdf

Cabero Almenara, J. (2007). Diseño y producción de tic para la formación. Barcelona: UOC.

Campbell, R., Holley, G. \& Metcalf, R. (2009): English in motion 3. Student's book. London: Richmond publishing.

Conselleria d'educació (2007). Decret 112/2007, de 20 de juliol, pel qual s'establix el currículum de l'eso a la comunitat valenciana.

Conselleria de cultura, educació i ciència (1999). Ordre de18 de juny, per la qual es regula l'atenció a la diversitat en l'educació secundària obligatòria.

De la Torre, A. (2006). Web educativa 2.0, Edutec: revista electrónica de tecnología educativa, 20. Retrieved from http://edutec.rediris.es/revelec2/revelec20/anibal20.pdf

Devries, D. \& Edwards, K. (1973). Learning games and student teams: their effect on classroom process, American Educational Research Journal, 10 (4), 307- 318.

Dodge, B. (1995). Some thoughts about WebQuests. Retrieved from http://webquest.sdsu.edu/about_webquests.html

Ellis, R. (1997). SLA research and language teaching. Oxford: OUP.

European Parliament and the Council (2006). Recommendation of the European Parliament and the Council of 18 December 2006 on Key Competences for Lifelong Learning. Official Journal of the European Union, $\quad$ 394. Retrieved from http:/leur-lex.europa.eu/legalcontent/en/txt/html/?uri=celex:32006h0962\&from=en

Eurostat (2013). DAE scoreboard 2013. Retrieved from https://ec.europa.eu/digital-agenda/sites/digitalagenda/files/dae\%20scoreboard\%202013\%20-\%203-internet\%20use\%20and\%20skills.pdf

Fernette \& Brock E. (2005). Brain of the blogger, Eide neurolearning blog. Retrieved from http://eideneurolearningblog.blogspot.com.es/2005/03/brain-of-blogger.html

Flew, T. (2008). New media: an introduction (3rd edition). Oxford: OUP.

llomäki, L., Kantosalo, A. \& Lakkala, M. (2011). What is digital competence? Retrieved from http://linked.eun.org/c/document_library/get_file?p_I_id=16319\&folderid=22089\&name=dlfe-711.pdf

Johnson, D.W. (2009). An educational psychology success story: social interdependence theory and cooperative learning. Educational Researcher 38(5): 365-379.

Cormode, G. \& Krishnamurthy, B. (2008). Key differences between web 1.0 and web 2.0. First Monday, 13 (6).

Kolb, D. A. (1984). Experiential learning. Experience as the source of learning and development. Englewood cliffs: Prentice-Hall.

Luzón, M.J., Ruiz-Madrid, M.N. \& Villanueva, M.L. (2010): Digital genres, new literacies and autonomy in language learning. Cambridge: Cambridge scholars publishing.

Lyman, F.T. (1981). The responsive classroom discussion: the inclusion of all students. In Anderson, A. (Ed). Mainstreaming Digest. University of Maryland Press, College Park.

Mctighe, J. \& O'Connor, K. (2005). Seven practices for effective learning. Educational leadership 63 (3), 10-17.

Moravec, J. (2008). Moving beyond education 2.0. Blog education futures. Retrieved from https://www.educationfutures.com/2008/02/15/moving-beyond-education-20/

Newby, T., Stepich, D., Lehman, J. \& Russell, J. (2000). Instructional technology for teaching and learning (2d ed.). Upper Saddle River: Merrill.

Nunan, D. (2004). Task-Based Language Teaching, Cambridge: CUP. 
Oster, U., Ruiz Madrid, M. N. \& Sanz Gil, M. (Eds.) (2006). Towards the integration of the ICT in language learning and teaching: reflection and experience. Castelló: Servei de publicacions de la Universitat Jaume I.

Palomo, R., Ruiz, J. and Sánchez, J. (2008): Enseñanza con TIC en el siglo XXI: La Escuela 2.0. Alcalá De Guadaíra: Mad.

Pérez Torres, I. (2006): Diseño De webquests para la enseñanza/aprendizaje del inglés como lengua extranjera: aplicaciones en la adquisición de vocabulario y la destreza lectora. Granada: Editorial Universidad de Granada. Retrieved from http://0Hera.Ugr.Es.Adrastea.Ugr.Es/Tesisugr/16171123.Pdf

Prensky, M. (2001). Digital natives, digital immigrants part 1. On the horizon, 9 (5), 1-6. Lincoln: NCB University Press. Retrieved from http://www.marcprensky.com/writing/prensky\%20\%20digital\%20natives, \%20digital\%20immigrants\%20-\%20part1.pdf

Quinn, K. (2013). Cooperative learning strategies. Alt conference. Retrieved from http://education.uwinnipeg.ca/pdf_files/handout $\% 20$ - 20 cooperative $\% 20$ learning\%20strategies.pdf

Resta, P. (ed.) (2002). Information and communication technologies in teacher education: a planning guide, Paris: Unesco.

Richards, J. C. (2006). Communicative Language Teaching Today. Cambridge: CUP.

Richardson, W. (2006). Blogs, wikis, podcasts, and other powerful web tools for classrooms. California: Corwin press.

Robinson, K. (2008). Ted talk: changing education paradigms. Retrieved from http://www.ted.com/talks/ken_robinson_changing_education_paradigms

Santiago, R. \& Navaridas, F. (2012). La web 2.0 en escena. Pixel-bit: revista de medios y educación, 41, 19-30.

Swain, M. (1985). Communicative competence: some roles of comprehensible input and comprehensible output in its development. In Gass, S. \& Maden, C. (Eds.). Input and second language acquisition. Rowley: Newbury house.

Tran, I. (2011). Bitstrips for schools. Teach. Retrieved from http://teachmag.com/archives/3381

Trenchs, M. (Ed.) (2001). Nuevas tecnologías para el autoaprendizaje y la didáctica de lenguas. Lleida: Editorial Milenio.

Vallima, J. \& Hoffman, d. (2008). Knowledge society discourse and higher education. Higher Education, 56(3), 265-285.

Vygotsky, I.S. (1962). Thought and Language. Cambridge: MIT press.

Vygotsky, I. S. (1978). Mind in Society. Cambridge: Harvard University Press.

Received: 03/03/2016

Accepted: 15/05/2016 